\title{
Effects of selected essential oils on the growth and production of ochratoxin A by Penicillium verrucosum
}

\author{
Barbara Jeršek ${ }^{1}$, Nataša Poklar Ulrih ${ }^{1,2}$, Mihaela Skrt ${ }^{1}$, Neda Gavarić ${ }^{3}$, Biljana Božin ${ }^{3}$, and \\ Sonja Smole Možina ${ }^{1}$
}

Department of Food Science and Technology, Biotechnical Faculty, University of Ljubljanal, Centre of Excellence for Integrated Approaches in Chemistry and Biochemistry of Proteins (CipKeBip)2, Ljubljana, Slovenia, Department of Pharmacy, Faculty of Medicine, University of Novi Sad, Novi Sad, Serbia ${ }^{3}$

Received in January 2014

CrossChecked in January 2014

Accepted in May 2014

\begin{abstract}
Essential oils from oregano (Origanum vulgare L.), mint (Mentha piperita L.), fennel (Foeniculum vulgare Mill.), and pine (Abies alba Mill.) needles and cones, and their active substances thymol, carvacrol, menthol, and anisaldehyde were tested for antifungal activity against Penicillium verrucosum. The lowest minimal inhibitory concentrations (MICs) were achieved for essential oil of oregano, followed by carvacrol, thymol, and menthol. These antifungal components were further investigated, as the main aim of our study was to elucidate the effect of natural antifungals on ochratoxin A production. During 21 days of exposure, the growth of $P$. verrucosum, and subsequently the production of ochratoxin A, was fully inhibited by thymol at $1 / 2$ MIC $\left(0.0625 \mathrm{mg} \mathrm{mL}^{-1}\right)$, but menthol at $1 / 4$ and $1 / 2$ MIC $\left(0.1875\right.$ and $\left.3750 \mathrm{mg} \mathrm{mL}^{-1}\right)$ showed no growth inhibition. After 21 days of incubation, the greatest inhibitory effect on ochratoxin production (inhibition was $96.9 \%)$ was also achieved with thymol at $1 / 4 \mathrm{MIC}\left(0.0313 \mathrm{mg} \mathrm{mL}^{-1}\right)$. Essential oil of oregano $(1 / 4 \mathrm{MIC}$, $\left.0.2930 \mu \mathrm{L} \mathrm{mL}^{-1}\right)$ and carvacrol $\left(1 / 2 \mathrm{MIC}, 0.1953 \mu \mathrm{L} \mathrm{mL}^{-1}\right)$ stimulate production of ochratoxin $\mathrm{A}$ at $13.9 \%$ to $28.8 \%$, respectively. The observed antifungal effects depended on the agent, the concentration used, and the time of interaction between the agent and P. verrucosum. Our results indicate the possibility of using oregano essential oil as a substitute for artificial preservatives in certain foods, but further research is needed.
\end{abstract}

KEY WORDS: anisaldehyde; carvacrol; food spoilage; menthol; minimal inhibitory concentration, natural antifungal agents; oregano; thymol

Moulds of the Penicillium, Aspergillus, Fusarium and Alternaria genera are known food spoilage microorganisms and mycotoxin producers that can cause significant economic losses (1-3). Ochratoxin A (OTA) is a very important mycotoxin, as it has teratogenic, embryotoxic, genotoxic, neurotoxic, immunosuppressive, and nephrotoxic effects (4). The International Agency for Research on Cancer (IARC) classified OTA as possibly carcinogenic to humans (group 2B) (5, 6). It can originate from producers such as Aspergillus ochraceus and Aspergilli from the section Nigri (A. carbonarius), Penicillium verrucosum, and Penicillium nordicum $(5,7)$.

Potential contamination with Aspergillus and Penicillium moulds and their growth depend on temperature, moisture content, and the time over which a food is exposed to adverse conditions. These processes can also be affected by the presence of spores, mechanical and insect damage, mineral nutrient availability, $\mathrm{pH}$ and carbon dioxide levels, and chemical and physical treatments applied to food (8). The presence of moulds in food does not 
necessarily mean that a food contains mycotoxins, and vice versa - mycotoxins can also be found in food without any presence of moulds. Given that OTA is a very stable mycotoxin that is not destroyed during standard food-production processes, it can be found both in raw foods and processed food products. OTA is most frequently found in cereals and cereal products, dried vine fruit, wine, coffee, pulses, beer, grape juice, cacao products, nuts, and spices (5).

Traditionally, control of mould growth and OTA production in foods has been performed by applying different chemical additives. Over the last decade, studies have investigated different natural antimicrobials that might replace these traditionally used chemical additives (9-11). Chemical preservatives have become less effective and can cause the development of resistant fungal strains (12-14). There are also increasing consumer demands to reduce the usage of synthetic fungicides and pesticides, and these requirements have led researchers to investigate naturally occurring compounds as alternatives to the use of chemical agents.

Different plant extracts and essential oils have already been shown to have antimicrobial/antifungal effects (14-18). These are commonly related to plant origin, extraction type, and chemical structure of their active substances. Prior to their application, potential natural antifungals need to be evaluated for their activity in order to determine their effectiveness not only for fungal growth inhibition but also for inhibition of mycotoxin production.

The aim of the present study was to investigate the antifungal effects of selected essential oils and their active substances through the evaluation of $P$. verrucosum growth and OTA production.

\section{MATERIALS AND METHODS}

\section{Essential oils and their active substances}

Essential oils of oregano (Origanum vulgare L.), mint (Mentha $\times$ piperita L.), fennel (Foeniculum vulgare Mill.), and pine (Abies alba Mill.) needles and cones (Amadea natura d.o.o., Zagreb, Croatia) were tested for antifungal activity against $P$. verrucosum. Furthermore, thymol, carvacrol, menthol, and anisaldehyde (Sigma-Aldrich, St. Louis, MO, USA) were used for testing as pure active substances of these essential oils. Dimethyl sulfoxide (DMSO) (Merck,
Darmstadt, Germany) was used as the solvent. DMSO was diluted as described in the section on the determination of minimal inhibitory concentrations (MICs).

\section{Plant material}

Leaves of cultivated plants of mint (Mentha $\mathrm{x}$ piperita L., Lamiaceae) were collected in July of 2010 in the Vojvodina province, Republic of Serbia. Oregano herb (Origanum vulgare L., Lamiaceae) and fennel fruits (Foeniculum vulgare L., Apiaceae) were obtained from the Institute for Studies on Medicinal Plants "Dr Josif Pancic" in Belgrade in 2010. The collected plant material was air-dried and samples were stored in double paper bags in a dry place without direct sunlight until hydrodistillation.

\section{Isolation of essential oils}

Essential oils were obtained by hydrodistillation according to European Pharmacopoeia IV (2002) (19), with $n$-hexane as a collecting solvent. The solvent was removed under vacuum and essential oils were dehydrated with anhydrous $\mathrm{Na}_{2} \mathrm{SO}_{4}$.

\section{GC/MS analysis}

Qualitative and quantitative analysis of oregano essential oil was carried out using a Hewlett-Packard 5973-6890 GC-MS system, operating in electron ionization (EI) mode at $70 \mathrm{eV}$, equipped with a splitsplitless injector $\left(200^{\circ} \mathrm{C}\right)$ and a flame ionization detector $\left(250{ }^{\circ} \mathrm{C}\right)$. Helium was used as carrier gas $\left(1 \mathrm{~mL} \mathrm{~min}^{-1}\right)$, and the capillary columns used were HP $5 \mathrm{MS}(30 \mathrm{~m} \times 0.25 \mathrm{~mm}$; film thickness $0.25 \mu \mathrm{m})$. The temperature programs were $60-280{ }^{\circ} \mathrm{C}$ at a rate of $3{ }^{\circ} \mathrm{C} \mathrm{min}-1$ and $60-260{ }^{\circ} \mathrm{C}$ at a rate of $3{ }^{\circ} \mathrm{C} \min ^{-1}$, respectively; the split ratio was 1:10. Coelution and MS analysis identified the separated compounds by comparing their relative retention times with those of authentic samples (Carl Roth GmbH, Karlsruhe, Germany). For the components for which authentic substances were not available the identification was based on matching their retention indices and mass spectra with NIST/NBS, Wiley libraries spectra, and literature data (20).

\section{Maintenance of mould strain and preparation of spore suspension}

The experimental work was carried out with Penicillium verrucosum CBS 302.48 from the collection of the Centraalbureau voor Schimmelcultures 
Fungal Biodiversity Centre of the Royal Netherlands Academy of Arts and Sciences (CBS-KNAW, Utrecht, The Netherlands). The strain was maintained on malt extract agar (Merck, Darmstadt, Germany) plates and stored in a refrigerator $\left(1-4^{\circ} \mathrm{C}\right)$. For each experiment, $P$. verrucosum was sub-cultured on malt extract agar plates (Merck, Darmstadt, Germany) and incubated at $25{ }^{\circ} \mathrm{C}$ for 10 to 14 days, to allow significant sporulation. The conidia were removed from the malt extract agar plates and suspended in $1 \mathrm{~mL}$ saline solution $\left(\mathrm{NaCl}, 8.5 \mathrm{~g} \mathrm{~L}^{-1}\right.$, in water) containing Tween 80 (Merck, Hochenbrunn, Germany) (0.1\%; v/v). The spore suspensions were adjusted to the final concentration of $10^{5}-10^{6}$ spore $\mathrm{mL}^{-1}$ using a BürkerTürk counting chamber (Brand, Germany).

\section{Determination of minimal inhibitory concentrations (MICs)}

The purpose of determining the MICs was to identify the concentrations of essential oils and their active substances that inhibit the growth of $P$. verrucosum and the production of OTA. The microdilution assay was used with RPMI-1640 medium (Sigma-Aldrich, St. Louis, MO, USA) to determine the MICs of the essential oils and their active substances $(18,22,23)$. These agents were dissolved in DMSO to prepare stock concentrations of $32 \mathrm{mg} \mathrm{mL}^{-1}$ for thymol and menthol and $100 \mu \mathrm{L} \mathrm{mL}^{-1}$ for carvacrol, anisaldehyde, and the essential oils.

These stock solutions were further diluted with RPMI-1640 medium (1:4 v/v) to $8 \mathrm{mg} \mathrm{mL}^{-1}$ for thymol and menthol and $25 \mu \mathrm{L} \mathrm{mL}^{-1}$ for the other agents. The solutions of the essential oils and their active substances $(50 \mu \mathrm{L})$ were then serially diluted with RPMI-1640 medium in 96-well microtitre plates and $50 \mu \mathrm{L}$ of $P$. verrucosum spore suspension was added to each well. The positive control encompassed three wells containing $50 \mu \mathrm{L}$ of RPMI-1640 medium with $50 \mu \mathrm{L}$ of spore suspension alone, whereas the negative control was three wells containing $50 \mu \mathrm{L}$ RPMI-1640 medium and the antifungal agents alone $(50 \mu \mathrm{L})$. Three wells were also used solvent control to determine if DMSO affects the growth of $P$. verrucosum. The preparation procedure was the same as for the dilutions of the antifungal agents, except that initially only $100 \mu \mathrm{L}$ of DMSO solution was added.

Once prepared, these plates were shaken on a microplate shaker (Eppendorf, Hamburg, Germany) for $1 \mathrm{~min}$ and incubated at $25^{\circ} \mathrm{C}$ for $48 \mathrm{~h}$. As an indicator of growth, $10 \mu \mathrm{L}$ p-iodonitrotetrazolium violet (Sigma Aldrich, Steinheim, Germany) $\left(2 \mathrm{mg} \mathrm{mL}^{-1}\right.$, in water) was added to the microplate wells, which were additionally incubated at $25^{\circ} \mathrm{C}$ for $48 \mathrm{~h}$.

The MICs were determined as the lowest concentration of an antifungal agent that inhibited $P$. verrucosum growth, whereby the solution in the well remained clear, with no change in colour. The selected unit for MIC was $\mu \mathrm{L} \mathrm{mL}^{-1}$ for essential oil of oregano, essential oil mint, essential oil pine needles, essential oil pinecones, essential oil of fennel, carvacrol and anisaldehyde as these essential oils and active substances were in liquid state and $\mathrm{mg} \mathrm{mL}^{-1}$ for thymol and menthol since they were obtained in a solid state.

\section{Effects of essential oils and their active substances on $\mathrm{P}$. verrucosum and production of ochratoxin $A$}

To determine the effects of the selected essential oils and their active substances on the growth of $P$. verrucosum and formation of OTA, Czapek Yeast Extract agar (CYA) (23) was used. Each agent was tested at $1 / 2$ MIC and $1 / 4$ MIC, previously determined in the microdilution assays.

After autoclaving, the CYA medium was cooled to $45{ }^{\circ} \mathrm{C}$ and solutions of the essential oil and their active substances were prepared for testing, which was performed on 10 Petri plates. Negative control plate contained only CYA medium, while the solvent control plates contained CYA medium with the two highest DMSO concentrations used to dissolve the tested substances $(0.2 \%$ of DMSO for control samples at thymol and menthol; $0.4 \%$ for other active substances). All of the CYA plates were three-point inoculated with the $P$. verrucosum spore suspension using a split needle and incubated at $25^{\circ} \mathrm{C}$. The diameters of the colonies were measured after 7,10 , 14,17 , and 21 days of incubation. In parallel, sampling for thin-layer chromatography (TLC) and highperformance chromatography (HPLC) was performed from the corresponding CYA plates. The formation of the OTA was determined qualitatively by TLC and quantitatively by HPLC. The antifungal activities were evaluated according to the mean fungal growth rates and are expressed as mean $\pm \mathrm{SD}$ (mm per day).

The screening for OTA production was performed using TLC. After 14, 17, and 21 days of incubation of the CYA plates, three agar plugs were removed from the central, sub-central, and boundary areas of the colonies and transferred to TLC plates using the agarplug method described by Samson and Hoekstra (23).

For the HPLC screening method (24), three-point inoculated CYA agar plates were analysed after 7, 14, 17, and 21 days of $P$. verrucosum growth at $25^{\circ} \mathrm{C}$. At 
each time, three agar plugs were removed from the central, sub-central, and boundary areas of the colony and introduced into a $1.5 \mathrm{~mL}$ tube. Then, $0.5 \mathrm{~mL}$ of methanol (Merck, Darmstadt, Germany) was added to each tube, which was shaken at $270 \mathrm{rpm}$ for $60 \mathrm{~min}$. From each of the test tubes, the supernatant was evaporated under a gentle stream of nitrogen and the residue was reconstituted in $0.2 \mathrm{~mL}$ mobile phase for HPLC determination. Solutions of OTA standards and extracts were analysed using an HPLC system that consisted of a 1260 Infinity model G1312B binary pump, a model G1367E autosampler, and a model G1321B fluorescence detector (Agilent Technologies, Inc., Wilmington, DE, USA). Data signals were acquired and processed on a PC running Agilent Chemstation (Agilent Technologies, Inc., Wilmington, DE, USA). The HPLC analyses were carried out using a ThermoHypersil-Keystone (ThermoHypersil, UK) Lichrosorb RP18 column (4.6x250 mm; $10 \mu \mathrm{m}$ particle size). The separation conditions for the OTA standard solutions and extracts were as follows: column temperature $25^{\circ} \mathrm{C}$; injection volume $20 \mu \mathrm{L}$; flow rate $0.8 \mathrm{~mL} \mathrm{~min}^{-1}$; time $60 \mathrm{~min}$. The excitation and emission wavelengths were set at $330 \mathrm{~nm}$ and $460 \mathrm{~nm}$, respectively. The mobile phase consisted of acetonitrile: water: acetic acid $(57: 41: 2 \mathrm{v} / \mathrm{v} / \mathrm{v})$. Acetonitrile was HPLC grade from Sigma-Aldrich (St. Louis, MO, USA), and acetic acid was analytical grade from Merck (Darmstadt, Germany). Chromatographic peaks were identified by comparing retentions and fluorescence spectra of the samples with those of the standard compounds. Quantitation was carried out by external standardization. Calibration standards in the range $0.2-1.0 \mu \mathrm{g} \mathrm{mL}^{-1}$ were prepared by serial dilution from a $10 \mu \mathrm{g} \mathrm{mL}^{-1}$ mixed standard. Calibration standards were prepared in HPLC diluent. Five concentration points were assayed in triplicate. The OTA levels in the extracts were calculated from the calibration curve $y=388.8 x-34.499$, where $y$ is the area response and $x$ the concentration of OTA in $\mu \mathrm{g} \mathrm{mL} L^{-1}$. The correlation factor was 0.9982 . The limit of quantification (LOQ) and the limit of detection (LOD) were calculated on the basis of the standard deviation of the response and the slope obtained from the linearity plot of the standard mixture of OTA. LOQ and LOD were calculated as $3.3 \alpha / \mathrm{S}$ and $10 \alpha / \mathrm{S}$, respectively, where $\alpha$ is the standard deviation of the $\mathrm{y}$-intercept and $\mathrm{S}$ is the slope of regression line. The LOQ and the LOD were $0.220 \mu \mathrm{g} \mathrm{mL}^{-1}$ and 0.073 $\mu \mathrm{g} \mathrm{mL}^{-1}$, respectively. The OTA recovery was determined as an average value $99.96 \%$. Since all of the tested agents were dissolved in DMSO, to determine their exact effect, results obtained for the solvent controls had to be subtracted from the values obtained by our measurements for $P$. verrucosum growth and OTA production. Than the inhibition (I) of growth and inhibition of OTA production were calculated as $\mathrm{I}(\%)=[(\mathrm{K}-\mathrm{O}) / \mathrm{K}] \mathrm{x} 100$, where $\mathrm{K}$ was a value taken from the control sample I(CYA medium), and $\mathrm{O}$ from the sample where the essential oil or its active substances were added. In cases where the production of OTA was higher than that of the control samples, the stimulation of OTA production was calculated as $\mathrm{S}(\%)=[(\mathrm{O}-\mathrm{K}) / \mathrm{O}] \times 100(9,14)$. Inhibition of growth was calculated from results obtained for $P$. verrucosum growth as diameter of colony $(\mathrm{mm})$ and inhibition (or stimulation) of OTA production was calculated from results obtained for $P$. verrucosum production of OTA $\left(\mu \mathrm{gL}^{-1}\right)$.

\section{Statistical analysis}

The experimental data for growth inhibition (I) were evaluated statistically using the SAS/STAT program (SAS Software, 1999; SAS Institute Inc., Cary, NC, USA). The basic statistical parameters were calculated by the MEANS procedure. The data were tested for normal distributions and analysed using the general linear model (GLM) procedure. The statistical model included the main effect of time of incubation $(14,17,21$ days $)$ and antifungal agent and its concentration (essential oil of oregano, thymol, carvacrol, menthol at $1 / 2$ and $1 / 4 \mathrm{MIC}$ ). The means were obtained using Duncan's procedure and compared at the $5 \%$ probability level.

\section{RESULTS AND DISCUSSION}

Essential oil of oregano thymol, carvacrol and menthol were selected for full testing of antifungal effects against $P$. verrucosum growth and OTA production. The criteria for selection were I) selection of one essential oil that has the lowest MIC among tested essential oils and II) selection of 3 active components that are present in tested essential oils and have the lowest MICs. According to these criteria, the essential oil of oregano and thymol and carvacrol as its main active components were selected. In addition, menthol as the third most active pure component was selected as well. 


\section{MICs of essential oils and their active substances}

Based on the obtained MICs, oregano essential oil and carvacrol had the highest antifungal effects on $P$. verrucosum (Table 1).

Table 1 Minimal inhibitory concentrations (MICs) for essential oils and their active substances determined against $\mathrm{P}$. verrucosum

\begin{tabular}{lc}
\hline Essential oil/active substance & MIC \\
\hline Essential oil of oregano & $1.1719 \mu \mathrm{L} \mathrm{mL}^{-1}$ \\
Essential oil mint & $6.2500 \mu \mathrm{L} \mathrm{mL}^{-1}$ \\
Essential oil pine needles & $9.3750 \mu \mathrm{LL}^{-1}$ \\
Essential oil pinecones & $6.2500 \mu \mathrm{L} \mathrm{mL}^{-1}$ \\
Essential oil of fennel & $2.343 \mu \mathrm{L} \mathrm{mL}^{-1}$ \\
Thymol & $0.1250 \mathrm{mg} \mathrm{mL}^{-1}$ \\
Carvacrol & $0.3906 \mu \mathrm{LL}^{-1}$ \\
Menthol & $0.7500 \mathrm{mg} \mathrm{mL}^{-1}$ \\
Anisaldehyde & $0.7813 \mu \mathrm{L} \mathrm{mL}^{-1}$ \\
\hline
\end{tabular}

P. verrucosum growth and OTA production in the presence of oregano essential oil and active substances

The effects of oregano essential oil (see Table 2 for chemical composition), thymol, carvacrol, and menthol on $P$. verrucosum growth are shown in Figure 1. Menthol at concentrations of $1 / 2$ MIC and $1 / 4$ MIC had no effects on the growth of P. verrucosum. Growth was slower in the presence of oregano essential oil ( $1 \frac{1}{2}$ MIC, $1 / 4$ MIC) and carvacrol (1/4 MIC), as well as clearly slower in the presence of thymol ( $1 / 4 \mathrm{MIC})$ and carvacrol ( $1 / 2$ MIC). Thymol at $1 / 2$ MIC led to full growth inhibition.

Table 3 shows the results regarding OTA production, which was followed over the same 21-day incubation period in CYA.

OTA production was inhibited, in all tested periods, by oregano oil only at $1 / 2$ MIC. After 14 and 17 days of incubation, the essential oil of oregano at $1 / 4 \mathrm{MIC}$ resulted in a 66.6-92.1\% inhibition of OTA production. Surprisingly, after 21 days, oregano essential oil led to a $28.8 \%$ stimulation of OTA production.

When thymol at $1 / 2$ MIC was added to the CYA growth medium, $P$. verrucosum was fully inhibited and there was no OTA production. The lower concentration of thymol ( $1 / 4 \mathrm{MIC})$ resulted in an $83.3 \%$ inhibition of $P$. verrucosum growth and an $>95 \%$ inhibition of OTA production after 21 days.

Carvacrol at $1 / 2$ MIC showed inhibition of $P$. verrucosum growth over the 21 days of incubation and a $13.9 \%$ OTA production stimulation. At its lower concentration ( $1 / 4 \mathrm{MIC})$, carvacrol still had an inhibitory effect on P. verrucosum growth and on OTA production.

At both concentrations, menthol had no effects on $P$. verrucosum growth, although there were high levels of OTA production inhibition.

In general, the $P$. verrucosum growth inhibition (Table 4) was the greatest in the first days of the incubation and then reduced regardless of the

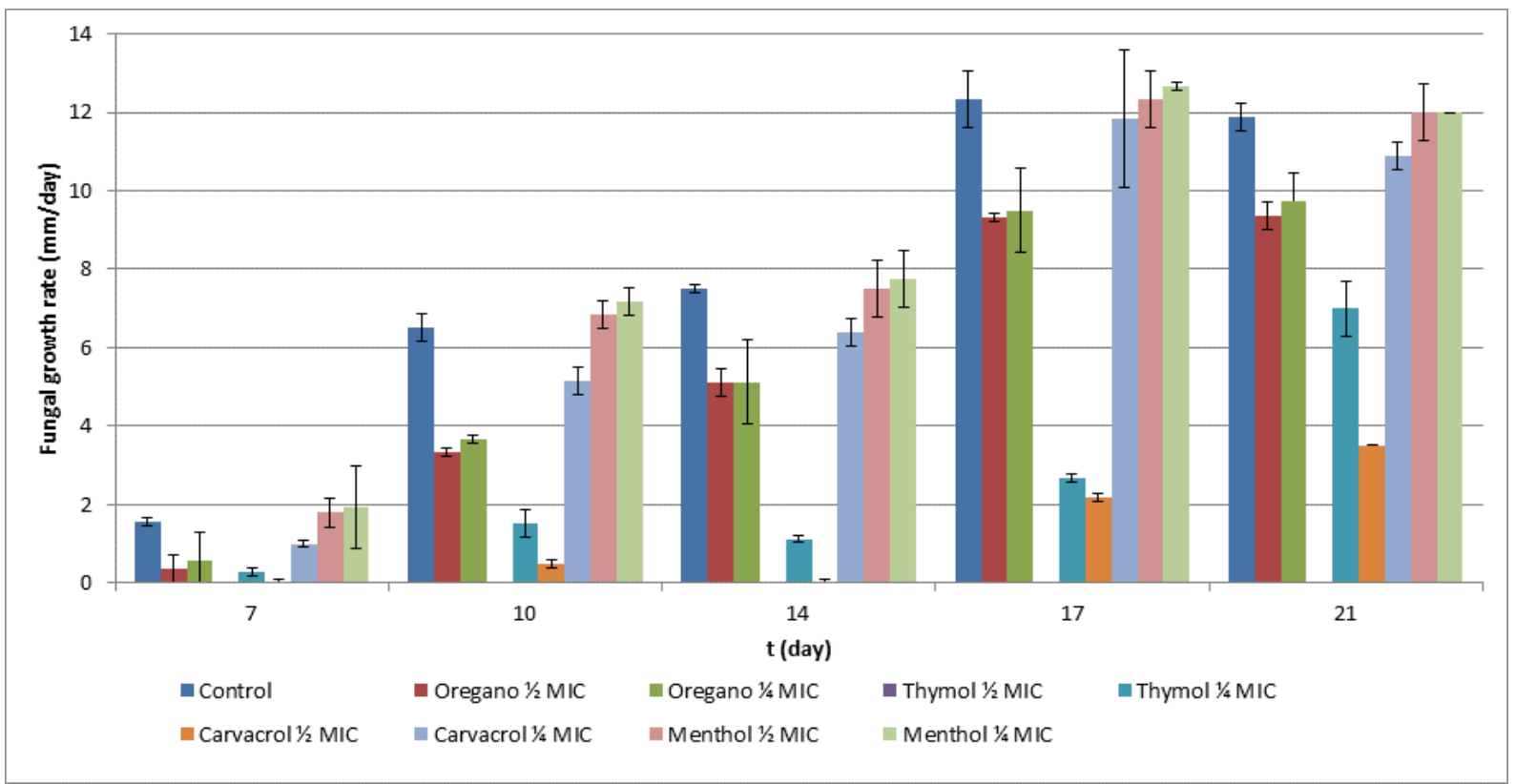

Figure 1 Mean P. verrucosum growth rates (mm per day) over a 21-day incubation with different antifungal agents at $1 / 2$ MIC and $1 / 4$ MIC. The bars indicate standard deviations for experiments carried out in duplicate 
Table 2 Chemical composition of oregano essential oil

\begin{tabular}{|c|c|c|c|}
\hline Pick No. & Compounds & R.I. ${ }^{a}$ & Percentage $(\%)$ \\
\hline \multicolumn{3}{|c|}{ Monoterpene Hydrocarbones } & 5.1 \\
\hline 3 & $\beta$-Myrcene & 0991 & 0.9 \\
\hline 4 & $\gamma$-Terpinene ${ }^{b}$ & 1060 & 4.2 \\
\hline \multicolumn{3}{|c|}{ Oxygenated Monoterpenes } & 11.4 \\
\hline 5 & trans-Sabinene hydrate & 1098 & - \\
\hline 6 & Linalool $^{\mathrm{b}}$ & 1097 & 4.8 \\
\hline 7 & Borneol $^{\mathrm{b}}$ & 1169 & 6.1 \\
\hline 8 & $\alpha$-Terpineol ${ }^{\mathrm{b}}$ & 1189 & 0.5 \\
\hline \multicolumn{3}{|c|}{ Aromatic Oxygenated Monoterpenes } & 59.9 \\
\hline 9 & Thymol methyl eter & & 0.6 \\
\hline 10 & Carvacrol methyl eter & 1245 & 0.9 \\
\hline 11 & Thymol $^{\mathrm{b}}$ & 1290 & 4.5 \\
\hline 12 & p-Cymene-7-ol & 1291 & 0.5 \\
\hline 13 & Carvacrol $^{\mathrm{b}}$ & 1299 & 53.4 \\
\hline \multicolumn{3}{|c|}{ Sesquiterpene Hydrocarbons } & 8.7 \\
\hline 14 & $\alpha$-Caryophyllene & 1409 & 0.2 \\
\hline 15 & trans Caryophyllene ${ }^{b}$ & 1419 & 1.6 \\
\hline 16 & Aromadendrene & 1441 & 0.4 \\
\hline 17 & $\alpha$-Himachalene & 1451 & 0.2 \\
\hline 18 & $\alpha$-Amorphene & 1485 & 0.2 \\
\hline 19 & $\beta$-Himachalene & 1505 & 1.6 \\
\hline 20 & $\beta$-Bisabolene & 1506 & 4.5 \\
\hline 21 & $\delta$-Cadinene & 1523 & - \\
\hline \multicolumn{3}{|c|}{ Oxygenated Sesquiterpenes } & 8.3 \\
\hline 22 & Caryophyllene oxide & 1583 & 4.5 \\
\hline 23 & $\alpha$-Cadinol & 1654 & 3.3 \\
\hline 24 & Farnesol $^{\mathrm{b}}$ & 1725 & 0.1 \\
\hline 25 & cis-Lanceol & 1761 & 0.3 \\
\hline 27 & Cedran-diol & 1898 & 0.1 \\
\hline \multicolumn{3}{|l|}{ Diterpenes } & 0.5 \\
\hline 28 & Abietatriene & 2057 & 0.5 \\
\hline \multicolumn{3}{|c|}{ Aromatic Hydrocarbons } & 1.1 \\
\hline & Anisole & 0.918 & 1.1 \\
\hline \multicolumn{3}{|c|}{ Aliphatic compounds } & 0.2 \\
\hline 2 & 1-Octen-3-ol & 0979 & - \\
\hline 26 & Octadecane & 1800 & 0.2 \\
\hline \multicolumn{3}{|c|}{ Identified compounds (\%) } & 95.2 \\
\hline
\end{tabular}

antifungal agent tested. OTA production prior to day 14 of incubation (for thymol at $1 / 4$ MIC and carvacrol at $1 / 2$ MIC also after 14 and 17 days could not be determined because the colonies were too small). Inhibition of OTA production did not accompany growth inhibition, which showed very different data (from $>95 \%$ inhibition to $>25 \%$ stimulation), which indicates the complexity of the $P$. verrucosum response mechanisms to these antifungals.

Our data show that, among the tested essential oils and active substances, the lowest MICs were obtained for oregano oil, thymol, carvacrol, and menthol.
Akgül and Kivanç (15) have already shown that the essential oil of oregano, thymol and carvacrol have strong antifungal activities, as they almost completely inhibited the growth of different Aspergillus, Mucor and Penicillium strains at $0.025 \%(\mathrm{w} / \mathrm{v})$ and $0.05 \%$ $(w / v)$. Sokolić-Mihalak et al. (18) investigated the effects of the essential oil of Thymus serpyllum $\mathrm{L}$. and thymol on ochratoxigenic strains of Aspergillus, demonstrating that the MICs for their $A$. niger and $A$. ochraceus strains ranged from $0.625-250 \mu \mathrm{L} \mathrm{mL}^{-1}$ for the essential oil and $0.0078-0.125 \mathrm{mg} \mathrm{mL}^{-1}$ for thymol.

Vasquez Beatriz et al. (17) reported that thymol inhibited Penicillium citrinum growth over 10 days 
Table 3 Mean P. verrucosum production of OTA during the 21-day incubations with the different antifungal agents at $1 / 2$ MIC and $1 / 4 M I C$

\begin{tabular}{|c|c|c|c|}
\hline \multirow{2}{*}{$\begin{array}{l}\text { Antifungal agent } \\
\text { (concentration) }\end{array}$} & \multicolumn{3}{|c|}{ Average production of OTA $\left(\mu \mathrm{g} \mathrm{mL}^{-1}\right)$ at different incubation period } \\
\hline & 14 days & 17 days & 21 days \\
\hline Control I & $0.177 \pm 0.025$ & $0.266 \pm 0.021$ & $0.081 \pm 0.001$ \\
\hline Control II & $0.135 \pm 0.002$ & $0.308 \pm 0.011$ & $0.144 \pm 0.013$ \\
\hline Essential oil of oregano ( $1 / 2 \mathrm{MIC})$ & $0.187 \pm 0.012$ & $0.314 \pm 0.013$ & $0.196 \pm 0.017$ \\
\hline Essential oil of oregano ( $1 / 4 \mathrm{MIC})$ & $0.194 \pm 0.028$ & $0.320 \pm 0.042$ & $0.254 \pm 0.042$ \\
\hline Thymol (1/2 MIC) & n.a. & n.a. & n.a. \\
\hline Thymol (1/4 MIC) & n.a. & n.a. & $0.128 \pm 0.017$ \\
\hline Carvacrol (1/2 MIC) & n.a. & n.a. & $0.240 \pm 0.029$ \\
\hline Carvacrol (1/4 MIC) & $0.189 \pm 0.034$ & $0.308 \pm 0.023$ & $0.185 \pm 0.011$ \\
\hline Menthol (1/2 MIC) & not done & $0.278 \pm 0.011$ & $0.177 \pm 0.008$ \\
\hline Menthol (1/4 MIC) & $0.151 \pm 0.039$ & not done & $0.156 \pm 0.013$ \\
\hline
\end{tabular}

OTA, ochratoxin A; Control I, production of OTA by P. verrucosum on MEA; Control II, production of OTA by P. verrucosum on MEA with addition of DMSO in the concentration used for dilution of antifungal agent;

n.a., not applicable as there was no growth or the colonies were too small;

The values are means of two repetitions \pm standard deviations

Table 4 Mean P. verrucosum growth inhibition and inhibition of OTA production during the 21-day incubations with the different antifungal agents at $1 / 2$ MIC and $1 / 4$ MIC

\begin{tabular}{|c|c|c|c|c|c|c|c|}
\hline \multirow[b]{3}{*}{$\begin{array}{l}\text { Antifungal agent } \\
\text { (concentration) }\end{array}$} & \multicolumn{6}{|c|}{ Incubation period (days) } & \multirow[b]{3}{*}{$p$} \\
\hline & \multicolumn{2}{|c|}{14} & \multicolumn{2}{|c|}{17} & \multicolumn{2}{|c|}{21} & \\
\hline & $\begin{array}{c}\text { Growth } \\
\text { Inhibition } \\
(\%)\end{array}$ & $\begin{array}{c}\text { Inhibition } \\
\text { of OTA } \\
\text { production } \\
(\%)\end{array}$ & $\begin{array}{c}\text { Growth } \\
\text { Inhibition } \\
(\%)\end{array}$ & $\begin{array}{c}\text { Inhibition } \\
\text { of OTA } \\
\text { production } \\
(\%)\end{array}$ & $\begin{array}{c}\text { Growth } \\
\text { Inhibition } \\
(\%)\end{array}$ & $\begin{array}{c}\text { Inhibition } \\
\text { of OTA } \\
\text { production } \\
(\%)\end{array}$ & \\
\hline $\begin{array}{l}\text { Essential oil of } \\
\text { oregano }(1 / 2 \text { MIC) }\end{array}$ & $31.7 \pm 1.9^{\mathrm{A}, \mathrm{z}}$ & 70.6 & $24.3 \pm 2.4^{\mathrm{B}, \mathrm{w}}$ & 97.9 & $21.0 \pm 1.5^{\mathrm{C}, \mathrm{z}}$ & 72.6 & $<0.0001$ \\
\hline $\begin{array}{l}\text { Essential oil of } \\
\text { oregano }(1 / 4 \mathrm{MIC})\end{array}$ & $31.7 \pm 5.8^{\mathrm{A}, \mathrm{z}}$ & 66.6 & $22.9 \pm 5.3^{\mathrm{B}, \mathrm{w}}$ & 92.1 & $17.9 \pm 2.6^{\mathrm{B}, \mathrm{w}}$ & 28.8 stim. & 0.0082 \\
\hline Thymol (1/2 MIC) & $100.0 \pm 0.0^{\mathrm{A}, \mathrm{x}}$ & n.a. & $100.0 \pm 0.0^{\mathrm{A}, \mathrm{x}}$ & n.a. & $100.0 \pm 0.0^{\mathrm{A}, \mathrm{x}}$ & n.a. & $<0.0001$ \\
\hline Thymol (1/4 MIC) & $71.7 \pm 1.9^{\mathrm{A}, \mathrm{y}}$ & n.a. & $58.1 \pm 2.0^{\mathrm{B}, \mathrm{z}}$ & n.a. & $41.0 \pm 2.5^{\mathrm{C}, \mathrm{y}}$ & 96.9 & $<0.0001$ \\
\hline $\begin{array}{l}\text { Carvacrol } \\
(1 / 2 \mathrm{MIC})\end{array}$ & $98.3 \pm 1.9^{\mathrm{A}, \mathrm{x}}$ & n.a. & $66.2 \pm 1.9^{\mathrm{B}, \mathrm{y}}$ & n.a. & $42.1 \pm 1.4^{\mathrm{C}, \mathrm{y}}$ & 13.9 stim. & $<0.0001$ \\
\hline $\begin{array}{l}\text { Carvacrol } \\
(1 / 4 \mathrm{MIC})\end{array}$ & $15.4 \pm 1.9^{\mathrm{A}, \mathrm{w}}$ & 69.2 & $5.4 \pm 6.5^{\mathrm{B}, \mathrm{t}}$ & 100.0 & $8.4 . \pm 1.6^{\mathrm{B}, \mathrm{t}}$ & 50.0 & 0.0225 \\
\hline $\begin{array}{l}\text { Menthol } \\
(1 / 2 \text { MIC })\end{array}$ & $1.6 \pm 1.9^{\mathrm{A}, \mathrm{t}}$ & not done & $1.3 \pm 2.6^{\mathrm{A}, \mathrm{ut}}$ & 100.0 & $0.5 \pm 1.0^{\mathrm{A}, \mathrm{u}}$ & 59.3 & 0.7118 \\
\hline $\begin{array}{l}\text { Menthol } \\
(1 / 4 \mathrm{MIC})\end{array}$ & $0.0 \pm 0.0^{\mathrm{A}, \mathrm{t}}$ & 87.7 & $0.0 \pm 0.0^{\mathrm{A}, \mathrm{u}}$ & not done & $0.0 \pm 0.0^{\mathrm{A}, \mathrm{u}}$ & 81.5 & / \\
\hline$p_{\text {time of incubation }}$ & $<0.0001$ & & $<0.0001$ & & $<0.0001$ & & \\
\hline
\end{tabular}

OTA, ochratoxin A

stim. - stimulation of OTA production; n.a., not applicable as there was no growth or the colonies were too small;

The values are means of four repetitions \pm standard error.

Level of significance: highly statistically significant: $\mathrm{p} \leq 0.001$. Means with a different superscript within a row $(A, B, C)$ differ significantly $(\mathrm{p} \leq 0.05)$. Means with a different superscript within column $(x, y, z, w, t, u)$ differ significantly ( $\mathrm{p} \leq 0.05)$ 
of incubation at $200 \mathrm{mg} \mathrm{mL}^{-1}$, but not at lower concentrations (100 and $50 \mathrm{mg} \mathrm{mL}^{-1}$ ). Murthy et al. (14) reported approx. a $60 \%$ inhibition of growth of the OTA-producing strains of $A$. ochraceus, A. niger and Penicillium sp. by the essential oil of Indian borage after 5 to 7 days of incubation. This plant contains the same active substances (thymol and carvacrol) as oregano $(16,25)$. The inhibitory effects of the essential oil of oregano on P. verrucosum growth were shown in the present study, and these effects might also be mediated by the content of the above mentioned isolated compounds.

Carvacrol was determined as the dominant compound in investigated oregano essential oil, followed by thymol, linalool, bisabolen, and caryoplyllene. This combination of different monoand sesquiterpene compounds clearly contributed to its antifungal and OTA production inhibitory activity. However, isolated compounds, especially thymol exhibited higher antifungal activity and notable inhibition of OTA production which may indicate that synergism is not involved in these activities. Also, despite similar effects, comparisons of studies are often difficult, or even impossible, because of the origins of the essential oils, or because of the different methodologies used for the evaluation of these antifungal effects. Also, the compositions of the essential oils are highly dependent on the plant varieties, and within the same variety, they can also depend on the geographical origin, geographical location, climatic conditions, and method of extraction (12).

\section{CONCLUSIONS}

Our data indicate that natural antimicrobial agents, like essential oils and their isolated constituents can be used as antifungals. However, prior to application, they need to be evaluated for their activity in terms of inhibition of both growth and toxin production. The essential oil of oregano ( $1 / 2 \mathrm{MIC})$ and thymol ( $1 / 4$ and $1 / 2$ MIC) and carvacrol ( $1 / 4$ MIC) can be safely used as substitutes for chemical additives in foods for the partial or complete inhibition of the growth of $P$. verrucosum and for the inhibition of OTA production over 21 days of incubation. However, these were in vitro results and behaviour of the essential oils and active agents in foods could be a lot different depending on many intrinsic and extrinsic factors.

\section{Acknowledgements}

The authors would like to thank the Slovenian Research Agency and Ministry of Agriculture and Environment of the Republic of Slovenia for financing the project CRP V4-1079. The authors also thank Dr Lea Demšar from Biotechnical Faculty for statistical analysis, Nina Hostnik for experimental work and Dr Ksenija Markov from Faculty of Food Technology and Biotechnology, University of Zagreb, for providing some of the tested essential oils.

\section{REFERENCES}

1. COMMISSION REGULATION (EC) No 1881/2006 of 19 December 2006 setting maximum levels for certain contaminants in foodstuffs [displayed 29 May 2014]. Available at http://eur-lex.europa.eu/LexUriServ/ LexUriServ.do?uri=OJ:L:2006:364:0005:0024:EN:PDF

2. COMMISSION REGULATION (EU) No $105 / 2010$ of 5 February 2010 amending Regulation (EC) No 1881/2006 setting maximum levels for certain contaminants in foodstuffs as regards ochratoxin A [displayed 29 May 2014]. Available at http://eur-lex.europa.eu/legal-content/EN/ ALL/?uri=CELEX:32010R0105

3. COMMISSION REGULATION (EU) No $165 / 2010$ of 26 February 2010 amending Regulation (EC) No 1881/2006 setting maximum levels for certain contaminants in foodstuffs as regards aflatoxins. [displayed 29 May 2014]. Available at http://eur-lex.europa.eu/LexUriServ/ LexUriServ.do?uri=OJ:L:2010:050:0008:0012:EN:PDF

4. Ochratoxin A. In: Evaluation of Certain Food Additives and Contaminants. Sixty-eight report of the Joint FAO/WHO Expert Committee on Food Additives (JECFA). Geneva: WHO, 2007. p. 169-80.

5. European Food Safety Authority (EFSA). Opinion of the scientific panel on contaminants in the food chain on a request from the commission related to ochratoxin A in food. EFSA J 2006;365:1-56.

6. Ochratoxin A. In: IARC Monographs on the Evaluation of Carcinogenic Risks to Humans. Some Naturally Occurring Substances: Food Items, and Constituents, Heterocyclic Aromatic Amines and Mycotoxins. Vol. 56. Geneva: WHO, IARC; 1993. p. 489-521.

7. Pitt JI, Marta H, Taniwaki M, Cole B. Mycotoxin production in major crops as influenced by growing, harvesting, storage and processing, with emphasis on the achievement of Food Safety Objectives. Food Control 2013;32:205-15. doi: 10.1016/j.foodcont.2012.11.023

8. Amézqueta S, González-Peñas E, Murillo-Arbizu M, López de Cerain A. Ochratoxin A decontamination: a review. Food Control 2009;20:326-33. doi: 10.1016/j.foodcont.2008.05.017

9. Angelini P, Nellini R, Pagiotti A, Vianello B. Antimicrobial activities of various essential oils against foodborne pathogenic or spoilage moulds. Ann Microbiol 2006;56:659. doi: 10.1007/BF03174972 
10. Dobre AA, Gagiu V, Niculita P. Preliminary studies on the antimicrobial activity of essential oils against food borne bacteria and toxigenic fungi. Food Technol 2011;35:16-26.

11. Jayasena DD, Jo C. Essential oils as potential antimicrobial agents in meat and meat products: A review. Trends Food Sci Technol 2013;34:96-108. doi: 10.1016/j.tifs.2013.09.002

12. da Cruz Cabral L, Fernández Pinto V, Patriarca A. Application of plant-derived compounds to control fungal spoilage and mycotoxin production in foods. Int J Food Microbiol 2013;166:1-14. doi: 10.1016/j.ijfoodmicro.2013.05.026

13. Kumar A, Shukla R, Singh P, Dubey NK. Chemical composition, antifungal and antiaflatoxigenic activities of Ocimum sanctum L. essential oil and its safety assessment as plant based antimicrobial. Food Chem Toxicol 2010;48:539-43. doi: 10.1016/j.fct.2009.11.028

14. Murthy PS, Ramalakshmi K, Srinivas P. Fungitoxic activity of Indian borage (Plectranthus amboinicus) volatiles. Food Chem 2009;114:1014-8. doi: $10.1016 / \mathrm{j}$. foodchem.2008.10.064

15. Akgül A, Kivanç M. Inhibitory effects of selected Turkish spices and oregano components on some foodborne fungi. Int J Food Microbiol 1998;6:263-8. PMID: 2978951

16. D'Antuono LF, Galletti GC, Bocchini P. Variability of essential oil content and composition of Origanum vulgare L. populations from a north Mediterranean area (Liguria Region, northern Italy). Annal Botan 2000;86:471-8. doi: 10.1006/anbo.2000.1205

17. Vazquez Beatriz I, Fente C, Franco CM, Vazquez MJ, Cepeda A. Inhibitory effects of eugenol and thymol on Penicillium citrinum strains in culture media and cheese. Int J Food Microbiol 2001;67:157-63. doi: 10.1016/S01681605(01)00429-9
18. Sokolić-Mihalak D, Frece J, Slavica A, Delaš F, Pavlović H, Markov K. The effects of wild thyme (Thymus serpyllum L.) essential oil components against ochratoxin-producing Aspergilli. Arh Hig Rada Toksikol 2012;63:457-62. doi: 10.2478/10004-1254-63-2012-2309

19. European Pharmacopeia. Vol. 2.8.12. $4^{\text {th }}$ ed. Strasbourg Cedex: Council of Europe; 2002. p. 183-4.

20. Adams RP. Identification of Essential Oil Components by Gas Chromato- graphy/Mass Spectroscopy. 4th ed. Carol Stream (IL, USA): Allured Publishing Co.; 2007.

21. Clinical and Laboratory Standards Institute. M38-A2. Reference method for broth dilution antifungal susceptibility testing of filamentous fungi; Approved standard. $2^{\text {nd }}$ ed. 2008 [displayed 27 March 2014]. Available at http://shopping. netsuite.com/c.1253739/site/Sample_pdf/M38A2_sample. pdf

22. Mavri A, Abramovič H, Polak T, Bertoncelj J, Jamnik P, Smole Možina S, Jeršek B. Chemical properties and antioxidant and antimicrobial activities of Slovenian propolis. Chem Biodivers 2012;9:1545-8. doi: 10.1002/ cbdv.201100337

23. Samson RA, editor. Introduction to Food- and Airborne Fungi. Utrecht: Centraalbureau voor schimmelcultures; 2000.

24. Bragulat MR, Abarca ML, Cabañes FJ. An easy screening method for fungi producing ochratoxin $\mathrm{A}$ in pure culture. Int J Food Microbiol 2001;71:139-44. PMID: 11789931

25. Stefanakis MK, Touloupakis E, Anastasopoulos E, Ghanotakis D, Katerinopoulos HE, Makridis P. Antibacterial activity of essential oils from plants of the genus Origanum. Food Control 2013;34:539-46. doi: 10.1016/j. foodcont.2013.05.024 


\section{Izvleček}

\section{Vpliv izbranih eteričnih olj na rast in tvorbo ohratoxina A pri plesnih vrste Penicillium verrucosum}

Eterična olja origana (Origanum vulgare L.), mete (Mentha piperita L.), janeža (Foeniculum vulgare Mill.), in borovih (Abies alba Mill.) iglic in storžev, ter njihove sestavine timol, karvakrol, mentol in anisaldehid smo testirali kot snovi z protiglivno aktivnostjo proti plesnim vrste Penicillium verrucosum. Najnižje minimalne inhibitorne koncentracije (MICs) smo določili eteričnemu olju origana, ter karvakrolu, timolu, in mentolu. Rast plesni vrste $P$. verrucosum je bila popolnoma inhibirana po 21 dneh inkubacije v prisotnosti $1 / 2$ MIC timola $\left(0,0625 \mathrm{mg} \mathrm{mL}^{-1}\right)$, medtem ko so eterično olje origana ( $\left.1 / 2 \mathrm{MIC}, 1 / 4 \mathrm{MIC}\right)$, timol (1/4 MIC) in karvakrol ( $1 / 2$ MIC, $1 / 4$ MIC) inhibirali rast plesni od 8,3 \% do $70.8 \%$. Dodatek mentola v koncentracijah $1 / 4 \mathrm{MIC}$ in $1 / 2 \mathrm{MIC}\left(0.1875 \mathrm{mg} \mathrm{mL}^{-1}\right.$ in $\left.0.3750 \mathrm{mg} \mathrm{mL}^{-1}\right)$ pa ni imel inhibitornega vpliva na rast plesni vrste $P$. verrucosum. Popolno inhibicijo tvorbe ohratoksina A smo določili le v primeru, ko je bila tudi rast teh plesni popolnoma inhibirana (pri $1 / 2$ MIC timola). Največjo inhibicijo tvorbe ohratoksina A (96,9 \%) po 21 dnevih inkubacije smo določili pri $1 / 4$ MIC timola $\left(0.0313 \mathrm{mg} \mathrm{mL}^{-1}\right)$. Pospešeno tvorbo ohratoksina A (od 13,9 \% do 28,8 \%) pa smo določili pri $1 / 4$ MIC eteričnega olja origana $\left(0.2930 \mathrm{mg} \mathrm{mL}^{-1}\right.$ ) in $1 / 2 \mathrm{MIC}$ karvakrola $\left(0.1953 \mathrm{mg} \mathrm{mL}^{-1}\right)$. Protiglivni vplivi so bili odvisni od testirane snovi, njene koncentracije ter časa interakcij med protiglivno snovjo in plesnimi vrste $P$. verrucosum. Rezultati nakazujejo možnosti uporabe eteričnega olja origana v živilih namesto kemijskih konzervansov. Ker pa so živila kompleksna okolja v katerih je potrebno upoštevati več dejavnikov, so potrebne nadaljnje raziskave.

KLJUČNE BESEDE: eterična olja; karvakrol; mentol; MIC; naravna protiglivna snov; origano; timol

\section{CORRESPONDING AUTHOR:}

\section{Barbara Jeršek}

Department of Food Science and Technology Biotechnical Faculty, University of Ljubljana Jamnikarjeva 101, SI-1000 Ljubljana, Slovenia E-mail: barbka.jersek@bf.uni-lj.si 